\section{Preventing London Flood}

THE possibility of catastrophic flooding in London has often been discussed, particularly since the disastrous floods in Florence. The idea of a barrier across the Thames to stop such a flood has been suggested on several occasions, but all schemes appear to have met with opposition, sometimes short-sighted, it seems. Professor Hermann Bondi, chairman of ESRO, who is very concerned about the possibility of flood, has just published a report called the London Flood Barrier. It seems that Professor Bondi was approached by the Ministry of Housing and Local Government in October 1966 to consider the whole question of a barrier, not only its desirability and practicality, but also its possible design. Professor Bondi admits that he is "not a civil engineer"--some may criticize the report on this ground alone-but a flood barrier may well be the type of problem which needs an outsider's view, cutting as it does across several interests. In any case, the report deserves serious consideration.

Professor Bondi could scarcely make the frightening consequences of a serious flood in central London more clear. As he says, "the case for preventing the flooding of a major part of London during a surge tide seems to me enormously strong. We are at risk all the time and further delay only invites the disaster". Statements like this, even if slightly exaggerated, should not be taken lightly. Rumblings like this were heard before the Aberfan disaster.

The advantages and disadvantages of a permanent rather than a movable barrier are also discussed by Professor Bondi. A permanent barrage or dam, with locks in the Woolwich region, although expensive, would be the best solution if seen in the context of a major plan for the development of the south-east. A barrier of this type would be an effective flood defence as well as adding to the amenities of the Thames. Regretfully, Professor Bondi concludes that this scheme would not answer the immediate problem. He therefore moves on to discuss a removable barrier; one which would only be put in place when there was imminent danger of a surge tide flooding central London. Such a barrier would have no use other than flood prevention.

He rejects the idea of a retractable barrier close to the mouth of the river. It should be possible to find a site further upstream where a narrower opening in the barrier would not seriously impede shipping. Three possible locations are suggested: just below the Ford Motor Works; just above Dagenham Dock; and in Woolwich Reach. In the case of the first two locations, a clear opening of $800 \mathrm{ft}$., or perhaps $750 \mathrm{ft}$., might be acceptable to shipping interests. In the case of Woolwich something in the range of $350-500 \mathrm{ft}$. might be considered if the river banks were cleared of mooring berths. These sites are compared with the barrier at Long Reach considered in previous reports of the consulting engineers which required minimum clear openings of $1,400 \mathrm{ft}$.

The Government appears not to be apathetic to proposals for a flood barrier. In a written answer to the House of Commons on February 20, Mr Anthony Greenwood, Minister of Housing and Local Government, mentioned that the Greater London Council has undertaken to investigate, in consultation with the Port of London Authority and navigation interests, the relative merits of the two types of barrier, fixed and movable, and the most suitable site for one. Presumably the Bondi report will be taken into account in these discussions. The minister is also going to consult the South East Economic Planning Council on the wider implications of the projects.

\section{Parliament in Britain}

\section{Technological Community}

THe Prime Minister, Mr Harold Wilson, was pressed last week to give more details of his proposals for a European Technological Community. Mr Norman St John Stevas suggested that it had been one of the Prime Minister's happier initiatives-the only one, another member interjected-and that it should be pursued with much more vigour. Dr David Owen said that it was foolishness to refuse to share the technology of Capenhurst nuclear fuel enrichment plant with other European countries. By doing this, the British Government was driving them to establish their own plants. $\mathrm{Mr}$ Heath thought that the Technological Institute was a better idea than the technological community, but that enrichment would be covered by the terms of the non-proliferation treaty. The Prime Minister was not very enlightening. He said that discussions about the community had been held with representatives of the Dutch Government; the West German Government had welcomed the idea. As for fuel enrichment, the British Government had said that it was prepared to join with Europe in the setting up of a system for the production of enriched uranium-235. Britain had more know-how than others, he said, but they had cheap electricity. (Oral answer, February 20.)

\section{Research and Develofment}

Dr Jeremy Bray, Joint Parliamentary Secretary at the Ministry of Technology, told Mr Gwynfor Evans, the only Welsh Nationalist member in the House, that research and development expenditure in England supported by his department in the year ending March 31 , 1967, had cost $£ 219.5$ million. Alas for Mr Evans, Dr Bray revealed that only an additional $£ 2$ million had been spent in Wales in the same period. (Written answer, February 20.)

\section{Channel Tunnel}

$M_{R}$ JoHn MoRRIs, answering questions for the Ministry of Transport, showed no inclination to cancel the Channel Tunnel project. Mr Clark Hutchinson said that the whole project was out of date, and asked when the Government would stop wasting public money and time on these futile projects. Mr Eric Lubbock asked for a pause in the plans to see how well the new hovercraft service using the SRN 4 went. Mr Morris said that the expected growth of traffic over the next thirty years showed that the tunnel was economically preferable to the alternatives. (Oral answer, February 21.)

\section{Computers}

MR Wedgwood BenN, Minister of Technology, said the number of computer installations in operation or on order in the UK in 1970 would be not less than 5,000 . Not less than 1,500 installations would by then be at the planning stage. These revised estimates would mean that more computer personnel would be needed. By 1970 , there would need to be 300 advanced programmers, 20,000 people falling into the category of systems designers or systems analysts, and 25,000 operators. (Written answer, February 22.) 